\title{
Business strategy in Mexican beer industry: a case applying game theory
}

\author{
VARGAS - Jose $^{*} \uparrow \&$ CAMBRONI - Armando \\ Centro Universitario de Ciencias Económicas y Empresariales Universidad de Guadalajara Periférico Norte 799 Edif. \\ G2017Núcleo Universitario Los Belenes Zapopan, Jalisco, 45100, México Tel. +523337703340 Ext.
}

Received November 30, 2012; Accepted April 15, 2013

In this paper the two major breweries in Mexico, Grupo Modelo and Cuauhtémoc Moctezuma Brewering Company (Cervecería Cuahtemoc-Moctezuma) are analyzed which already have long formed part of an oligopoly because these two companies account for more than $99 \%$ of beer market in this country. All this analysis is made from the perspective of game theory. The main objective is to analyze the effects of competition and advertising from one to another brewer from a standpoint of game theory. This analysis is based on one of the clearest examples that have existed for years in a matter of advertising and competition among soft drink companies Coca-Cola and Pepsi-Cola.

Brewing company, competition, oligopoly, advertising, game theory.

Citation: Vargas J., Cambroni A. Business strategy in Mexican beer industry: a case applying game theory. ECORFAN Journal 2013, 4-10:1067-1076

\footnotetext{
*Correspondence to Author (email: jgvh0811@yahoo.com)
}

$\dagger$ Researcher contributing first author. 


\section{Introduction}

Over the years and for over a century by Cuauhtémoc-Moctezuma and some years less Grupo Modelo have been dominant firms' quintessential beer industries in Mexico.

We are facing a clear oligopoly as data which gives us the INEGI (INEGI, 2012) as will be shown later, we can see that these two brewers groups comprise a large part of beer sales in the country.

The objective of this work is to find out based on game theory, through a self-designed game, trying to adapt to the situation that were living the two largest brewers in Mexico, Grupo Modelo and Cerveceria CuauhtemocMoctezuma, to the potential profits or losses they may bring to increase their investments in advertising, because as oligopoly competition is so marked and closed between these two is very hard and strong.

Knowing that Grupo Modelo has been the leader in sales since the fifties, only losing this leadership during some years of the eighties caused by the binding of its major competitors and Cervecería-Cuauhtemoc and Cervecería Moctezuma, and now knowing that the latter group is Heineken allied to one of the largest brewers in the world, the relevant question of this work is:

It is right and convenient for the Cuauhtémoc-Moctezuma group to increase its investment in advertising and image care in relation to his competitor?

And so to impose presence and respect as worldwide beer company as it has done with Grupo Modelo and Corona beer, and now that it has been acquired by Heineken.
It seems necessary to take the opportunity to unseat the leader.

\section{Historical background}

Both Grupo Modelo and Cervecería Cuauhtemoc-Moctezuma have taken over the market almost more than a century by Cuauhtémoc-Moctezuma and nearly a century by Grupo Modelo.

Each one has a great tradition of taste and preference within the population in Mexico. Despite the fact that Grupo Modelo emerged twenty five years after what is now known Cuauhtémoc-Moctezuma Group, Grupo Modelo has managed over the years to position itself as the number one brewer in Mexico, this is measured in sales per year.

\section{A. Cervecería Cuauhtemoc-Moctezuma}

On October 25, 1925 was inaugurated Cerveceria Modelo, SA (Grupo Modelo, 2012) in Mexico City, in the presence of Don Braulio Iriarte first president of Grupo Modelo.

Later Don Pablo Diez conducted a major expansion policy through various investments and acquisitions of breweries, malting and strategic partnerships to ensure the supply of important inputs, a strategy somewhat similar to that conducted Cuauhtémoc brewery in its infancy.

Among the companies that acquired Grupo Modelo are Cervecería de Toluca y Mexico in 1935, Cervecería Estrella (Star Brewery) and Cervecería del Pacífico (Brewery Pacific) in 1954, Cervecería Modelo del Noroeste (Northwest Modelo Brewery) in 1960 and Cerveceria Modelo in Torreon in 1966. 
Within 25 years, that is, in the fifties, Grupo Modelo was already the leader in Mexican beer market, outselling both Cerveceria Cuauhtemoc and Cervecería Moctezuma as by that time they were still separate companies.

Talking about leadership in sales, Grupo Modelo had remained over competitors before the eighties, but it breaks in mid-eighties with the union and merge of Cervecería Cuauhtémoc-Moctezuma, although Grupo Modelo regained leadership in 1991 that maintains until today.

Among the brands belonging to Grupo Modelo are: Barrilito, Estrella, Leon, Modelo Especial, Montejo, Negra Modelo, Pacifico, Tropical, Victoria and of course Corona which is perhaps the one that the most royalties and worldwide prestige has given to Grupo Modelo.

Grupo Modelo also handles to import some foreign brands, among which are Budweiser, Bud Light, Carlsberg, O'Dould'sy Tsingtao. Currently Grupo Modelo has eight plants in the country and a total installed capacity of yearly 35 million hectoliters.

\section{Market Analysis}

As has been said before Grupo Modelo and Cerveceria Cuauhtemoc-Moctezuma cover much of the beer market in Mexico, this is somewhat obvious, since watching the number of brands that possess or import each of these companies do not leave many more options within reach.
But to demonstrate the market structure of which it has been spoken, based on data obtained from the INEGI.

It is run the test concentration index Herfindahl-Hirshman (Dorado, 1995), so we can be sure that it is a oligopoly.

Applying the concentration index Herfindahl-Hirschman $(\mathrm{HH})$ yields a result of 0.43786842 .

The index Herfindahl-Hirschman concentration, according to the article published by Garcia (1994) is between zero and one.

The theory given in (Varian, 1980) tells that while the $\mathrm{HH}$ is closest to 1 is approaching and while monopoly is closest to 0 is closer to perfect competition structure.

But in practice it is said that from 0.18 being treated as a market with an oligopolistic concentration degree.

Thus it can be assumed, based on data and daily experience that the beer market in Mexico is under a clear oligopoly market structure with a HH of 0.43786842 .

In Table 1 presented below show that between fourteen leading production facilities all owned either by Grupo Modelo or Cuauhtemoc-Moctezuma. 


\begin{tabular}{|c|c|c|}
\hline ID & $\begin{array}{l}\text { Name of the } \\
\text { business }\end{array}$ & $\begin{array}{l}\text { State, } \\
\text { municipality, } \\
\text { locality, colony }\end{array}$ \\
\hline $\begin{array}{l}167461- \\
5800\end{array}$ & $\begin{array}{l}\text { Cervecería } \\
\text { Cuauhtemoc- } \\
\text { Moctezuma, S } \\
\text { A de CV. }\end{array}$ & $\begin{array}{l}\text { Baja California, } \\
\text { Tecate, Zona } \\
\text { Centro. }\end{array}$ \\
\hline $\begin{array}{l}1275867- \\
3165\end{array}$ & $\begin{array}{l}\text { Cervecería } \\
\text { Modelo de } \\
\text { Torreón SA de } \\
\text { CV. }\end{array}$ & $\begin{array}{ll}\text { Coahuila } & \text { de } \\
\text { Zaragoza, } & \\
\text { Torreón, } & \\
\text { Torreón, } & \\
\text { Colonia } & \text { San } \\
\text { marcos } & \end{array}$ \\
\hline $\begin{array}{l}11022917- \\
5806\end{array}$ & $\begin{array}{l}\text { Cervecería } \\
\text { Modelo SA de } \\
\text { CV }\end{array}$ & $\begin{array}{l}\text { Distrito federal, } \\
\text { Miguel } \\
\text { Hidalgo, } \\
\text { Miguel } \\
\text { Hidalgo, } \\
\text { Colonia } \\
\text { Anahuac } \\
\end{array}$ \\
\hline $\begin{array}{l}11812698- \\
2404\end{array}$ & $\begin{array}{l}\text { Cervecería } \\
\text { Modelo de } \\
\text { Guadalajara SA } \\
\text { de CV }\end{array}$ & $\begin{array}{l}\text { Jalisco, } \\
\text { Guadalajara, } \\
\text { Guadalajara, } \\
\text { Colonia del } \\
\text { Fresno }\end{array}$ \\
\hline $\begin{array}{l}11910633- \\
2195\end{array}$ & $\begin{array}{l}\text { Cervecería } \\
\text { Cuauhtemoc- } \\
\text { Moctezuma SA } \\
\text { de CV }\end{array}$ & $\begin{array}{l}\text { Jalisco, } \\
\text { Guadalajara, } \\
\text { Guadalajara, } \\
\text { Colonia Zona } \\
\text { Industrial. }\end{array}$ \\
\hline $\begin{array}{l}11910633- \\
2195\end{array}$ & $\begin{array}{l}\text { Cervecería } \\
\text { Cuauhtemoc- } \\
\text { Moctezuma, } \\
\text { SA de CV }\end{array}$ & $\begin{array}{l}\text { Estado de } \\
\text { México, Toluca, } \\
\text { Toluca de } \\
\text { Lerdo, Zona } \\
\text { Industrial, } \\
\text { Toluca }\end{array}$ \\
\hline $\begin{array}{l}12869372- \\
6063\end{array}$ & $\begin{array}{l}\text { Cervecería } \\
\text { Cuauhtemoc- } \\
\text { Moztezuma SA } \\
\text { de CV }\end{array}$ & $\begin{array}{l}\text { Nuevo león, } \\
\text { Monterrey, } \\
\text { Colonia Bella } \\
\text { Vista }\end{array}$ \\
\hline
\end{tabular}

ISSN-Print: 2007-1582- ISSN-On line: 2007-3682 ECORFAN $^{\circledR}$ All rights reserved.

\begin{tabular}{|c|c|c|}
\hline $\begin{array}{l}12875642- \\
6825\end{array}$ & $\begin{array}{l}\text { Compañía } \\
\text { Cervecera del } \\
\text { Tropico SA de } \\
\text { CV }\end{array}$ & $\begin{array}{lr}\text { Oaxaca } & \text { San } \\
\text { Juan Bautista } \\
\text { Tuxtepec, San } \\
\text { Juan Bautista } \\
\text { Tuxtepec, } \\
\text { Colonia } \\
\text { Hacienda } \\
\begin{array}{l}\text { Yucal. } \\
\text { El }\end{array} \\
\end{array}$ \\
\hline $\begin{array}{l}13590088- \\
4574\end{array}$ & $\begin{array}{l}\text { Cervecería del } \\
\text { Pacífico }\end{array}$ & $\begin{array}{l}\text { Sinaloa, } \\
\text { Mazatlán, } \\
\text { Colonia Centro. }\end{array}$ \\
\hline $\begin{array}{l}24475043- \\
4168\end{array}$ & $\begin{array}{l}\text { Cervecería } \\
\text { Modelo del } \\
\text { Noroeste SA de } \\
\text { CV }\end{array}$ & $\begin{array}{l}\text { Sonora, } \\
\text { Cajeme, Ciudad } \\
\text { Obregón, Zona } \\
\text { Industrial } \\
\text { Número } 2\end{array}$ \\
\hline $\begin{array}{l}24475043- \\
5507\end{array}$ & $\begin{array}{l}\text { Cervecería } \\
\text { Cuauhtémoc } \\
\text { Moctezuma del } \\
\text { Noroeste SA de } \\
\text { CV }\end{array}$ & $\begin{array}{l}\text { Sonora, } \\
\text { Novojoa, } \\
\text { Unidades } \\
\text { económicas } \\
\text { fuera } \\
\text { localidad, de } \\
\text { Parque } \\
\text { Industrial } \\
\text { Navojoa. }\end{array}$ \\
\hline $\begin{array}{l}13960883- \\
3838\end{array}$ & $\begin{array}{l}\text { Cervecería } \\
\text { Cuauhtemoc- } \\
\text { Moctezuma }\end{array}$ & $\begin{array}{l}\text { Veracruz. } \\
\text { Veracruz de } \\
\text { Ignacio de la } \\
\text { Llave, Orizaba, } \\
\text { Zona Centro. }\end{array}$ \\
\hline $\begin{array}{l}14035273- \\
6488\end{array}$ & $\begin{array}{l}\text { Cervecería } \\
\text { Cuauhtemoc } \\
\text { Moctezuma, } \\
\text { SA de CV. }\end{array}$ & $\begin{array}{l}\text { Veracruz. } \\
\text { Veracruz de } \\
\text { Ignacio de la } \\
\text { Llave, Orizaba, } \\
\text { Zona Centro. }\end{array}$ \\
\hline
\end{tabular}

Table 1
Vargas J., Cambroni A. Business strategy in Mexican beer industry: a cass applying game theory. 
All fourteen production facilities add up their weighted shares of Table 2 gives a total of 1. This results maybe because of rounding issues, but if only add the 5 final data yields a result of 0.99999759 , indicating that Grupo Modelo and Cervecería CuauhtemocMoctezuma account for over $99 \%$ of the U.S. beer market. According to some reports, the remaining small percentage is craft beer, which is obviously a percentage less than $1 \%$.

\begin{tabular}{|c|c|c|c|}
\hline $\begin{array}{c}\text { Economic } \\
\text { units }\end{array}$ & $\begin{array}{c}\text { Total } \\
\text { production } \\
\text { (Thousands } \\
\text { of pesos) }\end{array}$ & $\begin{array}{l}\text { Production/ } \\
\text { Total } \\
\text { production }\end{array}$ & $\begin{array}{l}\text { (Production/ total } \\
\text { production)^ } 2\end{array}$ \\
\hline 33 & 62113215 & & \\
\hline 14 & 0 & 0 & 0 \\
\hline$*$ & 150 & $2.41495 \mathrm{E}-06$ & $5.832 \mathrm{E}-12$ \\
\hline 4 & 6365 & 0.000102474 & $1.0501 \mathrm{E}-08$ \\
\hline$*$ & 9827 & 0.000158211 & $2.5031 \mathrm{E}-08$ \\
\hline 6 & 12964340 & 0.208721123 & 0.04356451 \\
\hline 3 & 12031480 & 0.193702419 & 0.03752063 \\
\hline 4 & 37101053 & 0.597313358 & 0.35678325 \\
\hline
\end{tabular}

Table 2

\section{Caso Coca-Cola and Pepsi Cola}

Over time for many years and in most of the world, the two major soft drink companies worldwide Pepsi and Coca Cola have been in a constant battle to try to be number one in global sales.

In different countries there have been fierce battles, according to Castro (2006) that has come to be present even in the courts.

This mainly for reasons of lack of competitiveness, by that this means unfair competition between the two companies.
A clear case of this call unfair competition, which is for example the case of México about the allegations that Coca Cola received when began offering refrigerators free of charge to small grocery stores, but with the condition that in that establishment only sell Coca Cola products.

Although also it is worth mentioning that the complaints have been against Coca Cola executives sometimes to go beyond unfair practices in trade. Some of their leaders have been accused of tax evasion, fraud, threats, and blackmail to murder.

As may know that Coca Cola has competition with other soft drink companies, mainly with Pepsi is extremely hard, and there are many examples as mentioned in different parts of the world.

There is a special worldwide counterexample that is the case in India where the firm Coca Cola was the leading soft drink sales in India until 1977 when, for reasons incoming government, which asked Coca Cola to disclose their formula and to dilute its stake in its Indian subsidiary as required by the Regulations of the foreign Exchange Act (FERA). In 1988, PepsiCo earned his entry to India by creating what Peng (2006) called a Joint Venture (venture) with the government-owned Punjab of India.

Then later, it breaks this joint venture between Pepsi and its partners Hindus in 1993 and Coca Cola returned because India began a new policy of liberation. And since 2005, Coca Cola and Pepsi Cola together control 95\% market share of soft-drink sales in India. 
But that case was, as mentioned above, very special and definitely something that marked and furthered this tremendous rivalry has been advertising and marketing, since in almost all major global event are present both Coca-Cola and Pepsi Cola with various advertisements.

A clear example of the above was the Pepsi Challenge, which took place in various parts of the world. Motivated by this example of competition between two worldwide "refreshments monsters".

This article has the task of trying to predict certain investment behavior of the two "brewers monsters" in Mexico. And it is what follows in the next section.

\section{Application of game theory to the case Model-Cuauhtémoc Moctezuma}

This section begins by giving a brief introduction of the effects it could have increased advertising expenses on sales.

\section{A. Brief explanation of advertising on sales of a company}

The relationship between advertising and sales is something that few doubt today.

However, the contributions of this type of communication to marketing actions are poorly understood. Numerous investigations realize the true influence of advertising on sales and decisions that can be taken from them for optimization.

\section{B. Indirect effects of institutional advertising}

According to the specialist Michael Ritter, mentioned by Cassella (2010) businesses that perform institutional advertising with their marketing communications have higher percentages of knowledge, memory and attitudes towards the brand. These percentages are ranging between 33 and 58 percent higher than the competition, says Ritter in "The influence of advertising and branding on business profitability".

\section{A greater investment in advertising, higher return on capital}

This is the conclusion reached by the Strategic Planning Institute (SPI) from a 1987 study. The research highlighted the influence that ad spending has on market share and how are perceived image attributes such as product quality or service.

According to SPI advertising influences the perception of quality that consumers have the product or service which brings two important consequences:

a) The higher the quality perceived by the consumer, the higher the price the company may request that the consumer is willing to pay.

b) The perception of higher quality also increases market share and this, in turn, increases the profitability again. 


\section{Application of the theory of advertising game theory in the case of Grupo Modelo and Cerveceria Cuauhtemoc-Moctezuma}

Considering what Miguel Ritter says about advertising in increasing sales ranging from 33 to 58 percent, it will then take the average of these two quantities to perform the game, take the percentage to calculate payments matrix is 45 percent.

Knowing in mind that it can be performed different types of games according to economic theory, this based on Varian (1980), as collisions between these companies which according to CFC (2010), there may be collusion because the fact that it is a market concentration is so marked is not legal that these companies are colluding.

So it becomes a game in a (López, 2012) and it comes with economic theory to find the best strategic decision (Peng, 2006), with which the agents will achieve profit maximization for the principals.

\section{Some common examples of game theory (Reading of Matrices and Nash Equilibrium).}

The following examples explained below are examples provided by (Varian, 1980) on Game Theory, which are among the most common that have been used over time to explain the best strategic decisions between companies.

According to (Varian, 1980) agents can adopt very different strategies in their relationships, many of which have been studied using the tools of game theory.

ISSN-Print: 2007-1582- ISSN-On line: 2007-3682

ECORFAN $^{\circledR}$ All rights reserved.
Below is a general explanation of how to read a payoff matrix in game theory. The next game (see Figure 1), it is present a twoperson game: A and B, A type "up" or "down" while B writes independently on other "left" or "right".

If A says "up" and B says "left", it examines the top left of the matrix.

The output of $\mathrm{A}$ is the first digit of the matrix 1, and the second $\mathrm{B}, 2$. So if $\mathrm{A}$ chooses "down" and B chooses "right", the result of A is 1 and $\mathrm{B}$ is 0 .

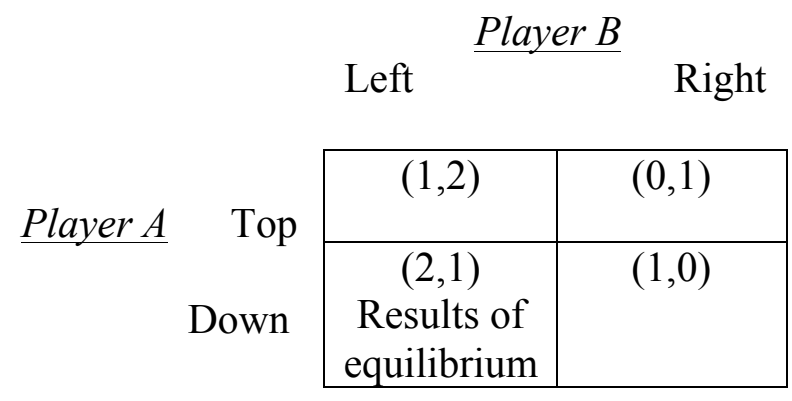

Figure 1

The solution of the game is "down" and "left", and that A gets up (1 or 0$)$, less than what you get at the bottom ( 2 or 1$)$. While B gets more left with ( 2 or 1$)$ than with ( 1 or 0$)$ to the right.

In this case it has a dominant strategy, where each player has an optimal strategy regardless of what the other does. (That strategy is best regardless of what the other player do). These strategies may represent economic choices and raise or lower the price or political elections and declare war or not.

Vargas J., Cambroni A. Business strategy in Mexican beer industry: a cass applying game theory. 
The results matrix of a game simply shows the results obtained by each player in each of the combinations chosen strategies.

\section{A- Nash equilibrium}

Not always there is equilibrium with dominant strategies (see Figure 2). The optimal choice of A depends on what you think will B. And best of $\mathrm{B}$ depends on what you do A. A pair of strategies is Nash equilibrium if the choice of $A$ is optimal, given that of $\mathrm{B}$, and $\mathrm{B}$ is optimal, given that of $\mathrm{A}$. Neither player knows what the other will do when you have to choose their own strategy, but you can have some expectations about what they will choose.

\begin{tabular}{c|c|c}
\multicolumn{2}{c}{ Left $\begin{array}{c}\text { Player } B \\
\text { PlayerA }\end{array}$} & $\begin{array}{c}(2,1) \\
\begin{array}{c}\text { Equilibrium } \\
\text { of Nash }\end{array}\end{array}$ \\
\cline { 2 - 3 }$(0,0)$ & $\begin{array}{c}\text { Top } \\
\text { Equilibrium } \\
\text { of Nash }\end{array}$ & Down \\
& &
\end{tabular}

Figure 2

The Nash equilibrium can be interpreted as a pair of expectations about the choice of each person so that when the other reveals his choice.

Not anyone of the two agents wants to change behavior. In this example there is a Nash equilibrium in $(2,1)$ "up" to the "left", because if $A$ chooses above, the best choice is left to B, and if B chooses "left", the optimal choice of A is "up". As (2.1) is also Nash equilibrium, for the same reasons.

\section{B. Rules}

It takes into account sales of Grupo Modelo and Cerveceria Cuauhtemoc Moctezuma for the game.

- 91.203 million pesos are the annual sales of Grupo Modelo.

- 77.691 million pesos annual sales are Cerveceria Cuauhtemoc Moctezuma.

\begin{tabular}{|c|c|}
\hline$(132,244.35$, & $(132,244.35$, \\
$112,651.95)$ & $77,691)$ \\
& \\
\hline$(91,203$, & $(91,203$, \\
$112,651.95)$ & $77,691)$ \\
\hline
\end{tabular}

It will take two actions which will advertise and publicize; advertise will be taken as: Increase investment in advertising, no publicizing will be taken as: No increase advertising spending.

It is assumed that the game is consecutive or sequential, i.e., one acts in relation to the decision of the other. For the example in question is supposed to Cerveceria Cuauhtemoc-Moctezuma will act on the decision of the Grupo Modelo. Below is the payoff matrix resulting from the abovedescribed amounts.

\section{Payoff matrix}

In the matrix shown (see Figure 3), there is a dominant strategy which is (advertise, publicize), i.e. $132,244.35,112,651.95$. This implies that Grupo Modelo always advisable to publicize, therefore it will choose the top part of the matrix. 
Given this, Cerveceria CuauhtemocMoctezuma will analyze its options, and also in advertising is that it gets higher payments, so surely choose to advertise, because it knows what it has chosen Grupo Modelo.

\section{Cervecería Cuauhtémoc Moctezuma Advertise No advertise}

Advertise

$$
\text { Grupo Modelo }
$$

No advertise

Figure 3

The point (advertise, advertise), i.e. $(132,244.35,112,651.95)$, also represents a Nash equilibrium, since at that point neither have incentives to move, given the choice of one produces the best profit for the another and vice versa.

\section{Conclusions}

This paper discussed how the two major brewers in the country, interact over and over to get the biggest gains to give birth to an analysis of how feasible it would increase its advertising spending.

It posed a straight consecutive game in which states that every company can obtain a 45 percent increase over earnings if invest on advertising.

The results given by this model is that the optimal strategy for one and other business is that advertise, at this point there is a dominant strategy and Nash equilibrium.
Therefore it can be concluded from the game raised, that in any event it suits Grupo Modelo invest more in advertising, and given this decision Cerveceria CuauhtemocMoctezuma continue along the same path, as it is the point that is more convenient for both.

\section{References}

CASSELLA, R. (2010). "Los efectos de la publicidad sobre las ventas". Economía $y$ Empleo.

CASTRO, G. (2006). Coca Cola, la Historia Negra de las Aguas Negras. CIEPAC.

CFC. (02 de 06 de 2010). México, México.

DORADO, H. (1995). Algunas Consideraciones para el Uso de Indicadores en el Estudio de la Estructura de Mercados. Trimestre Económic. Vol 16.,pp.27-35

FEMSA. (06 de 06 de 2012). México.

GARCÍA, P. (1994). Un índice de Dominación para el Análisis de la Estructura de los Mercados. El Trimestre Económico .Vol 65., pp. 7-17

GRUPO CUAHTEMOC-MOCTEZUMA (2012).

GRUPO MODELO. (s.f.). Recuperado el 01 de 06 de 2012, de 2012: http://www.gmodelo.mx/historia.jsp

GRUPO MODELO. (26 de 05 de 2012). México. 
INEGI. (03 de 06 de 2012). México.

PENG, M. (2006). Estrategia Global. México, México: Cengage Learning Editores, S.A. de C.V. (2010).

ROJAS, J., \& RODRÍGUEZ, R. (2010). Venta Cervecería Cuauhtémoc Moctezuma, la hegemonía de la Inversión Extranjera Directa. Economía Actual.Vol 26., pp. 1-7

SAAVEDRA, A. (12 de 01 de 2012). Heineken adquiere FEMSA Cerveza. El Economista.

LÓPEZ, A. (2012) "Teoría de Juegos y la Estratégia Empresarial". (s.f.). Managers Magazine. Instituto Nacional de Contadores Públicos de Colombia.

VARIAN, H. (1980). Microeconomía Intermedia. Barcelona: Antoni Bosch. 